\title{
Empowering Vocational Students' Literacy Skills through Project Based Learning
}

\author{
Arik Susanti \\ Universitas Negeri Surabaya \\ Surabaya, Indonesia \\ ariksusanti@unesa.ac.id
}

\author{
Anis Trisusana \\ Universitas Negeri Surabaya \\ Surabaya, Indonesia \\ anistrisusana@unesa.ac.id
}

\begin{abstract}
Nowadays, Indonesia has been a part of the ASEAN Economic Community so that it requires human resources that are able to compete in the working world. Accordingly, it is expected that vocational high school students must have literacy skills in order to increase students' competitiveness. However, the facts show that the students' literacy skills are still low since the learning process is still theoretical and textbook oriented. Consequently, the learning process becomes less effective and efficient. This research focuses on using Project Based Learning to improve the students' literacy skills. It is a learning method which can make the teaching and learning process become more meaningful for students. The research subjects are students from two vocational schools in rural and urban areas. The data collection methods include focus groups, semi-structured interviews, and observation. Quantitative analysis using percentage is used to analyze the gained data. The results of data analysis show the improvement of students' literacy skills to help them to be successful in the 21st century global community and economy. Qualitative results show the perceptions of the most improved literacy skills.
\end{abstract}

Keywords - literacy; project based learning; EFL

\section{INTRODUCTION}

Vocational high school is an educational institution of which main goal is to generate qualified graduates possessing entrepreneurial passion, qualified skill, and ability to compete in the global market. The vocational education system is designed to prepare its students to be professional and fulfill the needs of the world of work [1]. Vocational education is an effective tool to improve the potential and productivity of the individuals who face with the global problems like competition, specialization and employment [2]. Vocational students must have soft skills that are suitable with their job fields to face the world's competition [3]. Creative thinking and literacy are considered as employability skills or soft skills which are highly needed to be taught in vocational high school [4].

Creativity refers to the capacity of coping with a given problem in authentic ways. Creativity is beyond creating out of nothing since a new idea or though is often a variation version of an older thought or a combination of thoughts known or possessed previously. Thus, creativity can be defined as synthesizing previous thoughts and redefining previous thoughts. Creativity is a basic skill included in all aspects of human beings' life and evolution of human beings. Creativity consists of flexible, fluent, and authentic thinking in different situations [5]. Flexibility is the ability of adapting to changing conditions; fluency as quick sequencing of ideas; and authenticity as giving unique responses. When students have creative thinking skills, they can encourage themselves to create something new and useful for their life.

Creative thinking is a cognitive skill to generate and develop new ideas as the development of previously born ideas and the skills to solve problems from divergent angles. To encourage and develop creative thinking skills, students must have literacy skills to support their creative thinking skills [6]. Most people think that literacy is the ability to read and write. However, the concept of literacy becomes broader. Literacy is the ability to interpret, communicate, and share new forms of information in order to enhance or develop knowledge, skills and attributes [7]. Being literate includes using critical and creative thinking, conveying information in a multimodal ways of communication, applying knowledge and skills, and connecting various contexts.

Literacy skill is often considered as an important skill to be developed since the skill is very essential to face various problems in this competitive world. Therefore, it is believed that literacy skill must be achieved by students in the process of teaching learning, especially in learning English. Having literacy skill, students can develop their creative ideas to answer their challenge or realize their ideals. It can also motivate them to read various sources of reading materials because reading is a process where students' prior knowledge interacts with print to construct meaning. In this activity, the students will try to collect information, understand, analyze, and create something new in their society so that they will be successful people in their country and finally they will be the next leader. Moreover, they are also ready to face the work field after graduating from their school.

However, the facts show that there are many problems faced by the Vocational High School students when they are learning English. Most of them are passive learners. They often feel afraid when they have to speak English at the class. The result of preliminary observation tells that it is caused by the students' literacy competence that is still low. Most students are not familiar with English texts because they do not have 
reading habit, especially for English texts. In their leisure time, they prefer playing games to reading books. Moreover, teachers tend to use only text books in the process of teaching and learning [8]. It seems that they ignore the potential use of authentic materials as an alternative of learning sources.

Furthermore, the process of teaching learning is still dominated by the traditional method such as lecturing or explaining materials, giving questions, and asking the answers [8]. It makes students have less opportunity to practice their English. They tend to focus on the theory of language rather than the language practice. They never develop their creativity since the teachers never give the model how to be a creative person.

To overcome those problems, Project Based Learning $(\mathrm{PjBL})$ as an innovative learning model can be used in the process of teaching learning to improve the students' literacy. Project-based learning is an instructional model that is based on the constructivist approach to learning such as discovery learning, zone of proximal development, scaffolding, cognitive apprenticeship, coaching, context, collaborative learning, and the nature of assessment [9]. Constructivism aims at the construction of knowledge and entails the construction of knowledge with multiple perspectives and within a social activity. In PjBL environments, students learn primarily by constructing knowledge and making meaning through interactive processes of questioning, active learning, sharing, and reflection. It service learning emphasizes educational opportunities that are interdisciplinary, student-centered, collaborative, and integrated with real-world issues and practices [10]. Through PjBL, students become intrinsically motivated, more focused, and they develop a range of abilities and skills [11]. PjBL can build the students' literacy and creative thinking skills as they acquire a deeper level of learning and understanding of the subject-matter [12]. In addition, PjBL also enables teachers to teach skills beyond the content, make learning more personalized and more varied, and teach academic content more effectively [13]. Students are able to move from novices to experts in the domain of knowledge [14]. Their critical thinking abilities, their presentation skills, their communication skills, and their ability to work effectively on a team are also enhanced [11] [15]. Additionally, students value the fact that their projects are situated in real-life contexts [16].

Through PjBL, students can practice and continue to develop their literacy skills. PjBL requires more than just reading and writing, it draws upon all aspects of a student's literacy skill set [17]. Students acquire literacy through acquisition. Students mainly learn the skills they need by doing rather than being explicitly taught [14]. Once they have the opportunity to immerse themselves and practice their skills, they have more ownership over them and their literacy skills increase.

Based on the background of the study, the aims of the research are to investigate the improvement of students' literacy skills in learning English using PjBL and to describe the perceptions of the most improved literacy skills after the implementation of PjBL for vocational English.

\section{RESEARCH METHOD}

The purpose of the research is to investigate how Project Based Learning can improve the students' literacy in learning English. The settings of research were two schools of vocational high school located in East Java. They were private schools but they were in different areas. The first private vocational school was in suburb and the other in urban area in East Java. The subjects of this research were students who were in twelfth grade and they were in engineering department. The reasons why it was taken these students since they had job application letter materials and they would prepare how to apply the job after they graduate from this vocational school. Moreover, most of the students in vocational high school preferred to get a job after they finished from this school rather than to continue their high education. Besides, the students have also learned English for Special Purposes. By implementing this model, it would be measured the students' literacy skills since literacy skills are very important to face in their life. There were ninety subjects that were chosen randomly. It means there were no special requirements to decide the subjects.

The main instruments were test and observation sheet. Observation sheet was used to describe the process of teaching learning using Project Based model and the test was used to measure the students' literacy skills. However, it was also used interview instrument to find the data that was not got from observation sheet. The procedure how to collect the data could be explained. The first, it was designed lesson plan based on project based learning model. In lesson plan, it has been decided the project that was writing job application letter and curriculum vitae. All the projects must be done in group. The next stage was getting permission to school that the researcher would conduct this research for a moment. After that, it could do the research by implementing teaching Job application letter using Project based learning. There were some steps that must be conducted to teach English using Project based learning. Deciding the project is the first step in which the students were showed what kind of project that must be done. Then, making plan, in this stage, the students and teacher figured out project details that guided them from the opening activity to the completion of the project. The students should consider their roles, responsibilities, and collaborative work groups. They should also arrange the timing for gathering, sharing, and compiling information, and then presenting their final project. After that, doing research, here teacher prepared students for the demands of information gathering such as the language, skill, and strategy demands to complete their project. The teacher must be aware of students' levels in order to prepare instructional activities for each of the information-gathering tasks. Because the projects were writing job application letter and $\mathrm{CV}$, the teacher asked every group to browse the English sources on the Internet and then recommended some websites for their references. Moreover, the teacher reviewed the format of job application letter, the language, and the format of CV. It was used to guide the students to finish the project. After that, the students practiced the literacy skills and strategies needed for gathering 
information. To start writing job application letter, the students could readily collect information and search job vacancy using internet, or library searches. After that, they started to identify information that is critical for the completion of their project, related to job application letter. The students compiled and analyzed the gathered information. In their work, they organized information and then discussed the value of the data that they have collected, keeping some and discarding others. In this step they learned how to be critical person. After that, they tried to write job application letter and the first things that they must write was the contact information, address the letter with a name or title, express their interest or state the position to be applied and how they will benefit the employer. It was written in the first paragraph. In paragraph two, they were writing their strength, qualification and experiences. And in the third paragraph, they wrote their expectation that the manager would invite to contact them to join in interview section. The last, the students must sign and write their name.

If every group finished writing job application letter, they must write Curriculum Vitae that are relevant to it. Again, in this chance, the students identify, collect, keep information to complete the project. The teacher could help the students to master the language, skills, and strategies needed to compile, analyze, and synthesize the information that they have collected from their sources. The last step was sharing results. Here the students presented the final product. They must reflect on the language mastered and the subject matter acquired during the project. They were also asked to make recommendations that could be used to enhance similar projects in the future. The teacher provided students with feedback on their language and content learning.

After the process of teaching and learning English using Project based model was conducted, the next step to collect the data was submitting the students' projects and finally they would be assessed. Since the data was in the form of number then, the data was analyzed quantitatively. However, the data got from interview would analyzed quantitatively because they were in the form of words.

\section{RESULT AND DISCUSSION}

Project based learning was implemented to motivate and to know the students' literacy skills. The students were taught English using project based learning model in order they could increase their literacy skills. The table 1 shows the students literacy from Senior Vocational High School X.
CHART 1. STUDENTS' LITERACY SKILLS FROM SMK X

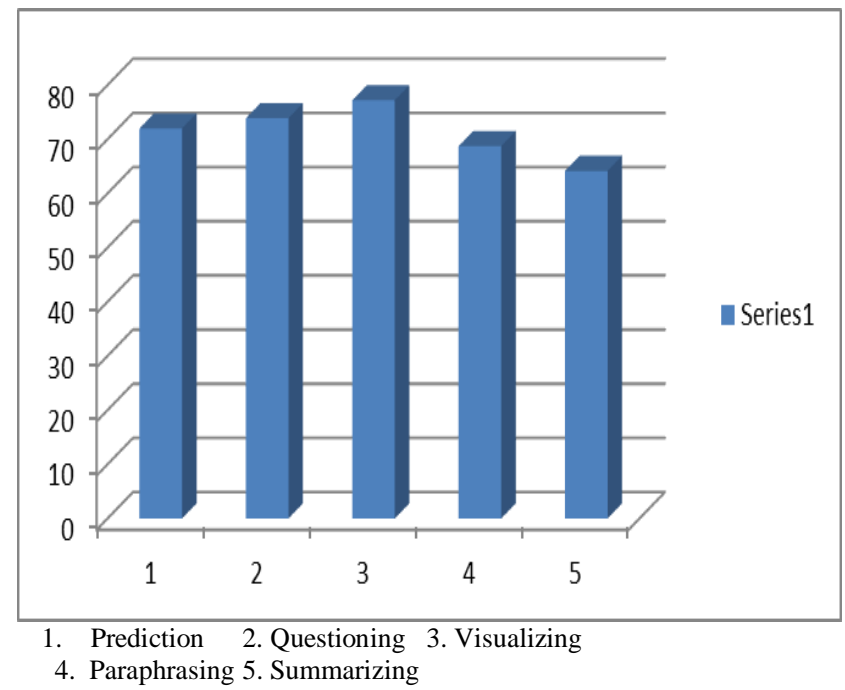

From chart 1, it was discovered that the students were easily understood in the visualizing aspect. In this aspect, the students' score was the highest, that was about 75. In this activity, the students were given such kind of graphic organizer and asked to implement such kind of texts given by the teacher. However, the most difficult aspect in literacy skill was summarizing (the average score was about 64) and it was continued by paraphrasing activity. From the table, it could be seen that the average score of paraphrasing was 68. This condition was caused that the students had lack of motivation to read the text. In this activity, most of them get difficulty to find the meaning of the words so that they were unable to guess the meaning from the context. Another factor showed that the students usually translate every word that they have read in their native language. When the teacher asked them to write a summary of the text, they found difficulty.

Chart 2 would present the results of literacy skill from vocational high school in Y school.

CHART 2. STUDENTS' LITERACY SKILLS FROM SMK Y

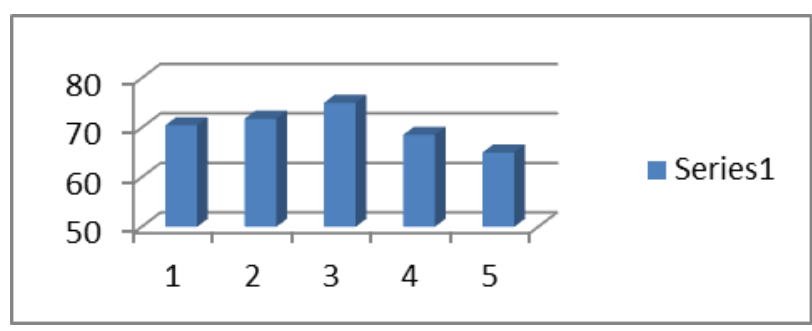

From the chart, it could be seen that the highest competence in literacy skill was visualizing. Most of the students got 73 score. The competence of making prediction and questioning 
were almost the same, that was about 70 . On the other hand the worst competence is summarizing, that was about 63 .

If it was compared the competence of students' literacy skills between the students in SMK X and SMK Y, it could be analyzed that both of the students got difficulty to write summary. This condition was caused that all the students dislike reading English text. Moreover, they had habits to translate the words in their native language. There were some reason why the prediction and questioning aspects become their favorite activities. In the prediction step, the teacher showed the students some pictures and they try to make prediction about the picture. Furthermore, the teacher also showed some titles of the text and asked the students to guess what the topic of the story were about. According to students, this activity was more challenge. In this activity, the students were free to use their own vocabulary and sometimes they said in their native language. The teacher, of course, provided some sets of vocabularies and asked the students to write the new vocabularies that were required. After that, the students used the new vocabularies to express their opinion. Based on the tables above, it can be seen that the average score of prediction skill in school $\mathrm{X}$ is higher than students in school Y. The students' competence in questioning skill between students in SMK X and SMK Y are almost the same. It was about 70. Questioning skills is also attractive activity for the students since the teacher applied many color in his texts. It is such kind of trigger for the students to create question related to the text. In this step, the students practice to create many questions in completing their project. Visualizing skill become the most favorite activity for both students. Here, the teacher used graphic organizer teach visualizing skill. The students read the text and write their finding in the form of graphic organizer.

It can be said that three skills were required the teacher's assistance and creativity to deliver the English subject. However in paraphrasing and summarizing skills, the students would be independent learners to comprehend the text. The students should understand the text by paraphrasing the difficult word to associate with their native words. Here, the students' translation was limited. They tried to work in group so that they would communicate their opinion, their suggestion and their denying if they disagree with their friends. Besides, they tried to write summary and perform their summary in front of the class. Two skills were the most difficult for the students both in SMK X and SMK Y.

After the students had thought that literacy was already embedded into the core PBL model of creating a driving project, they tried to appreciate others when they had different arguments or opinion. Then, they could show their writing in the form of gallery art and it would be displayed in the classroom or presented in front of the class. All the process of teaching learning made the students was active during in the class.

Based on the results of observation, interview and test, it was known that the students' literacy skills were good since the teacher implement learners' centered. The teacher also used many kinds of media that attract the students' interest.
Moreover, authentic materials are also used that can be seen from the activity in which the students were asked to search job vacancy in the internet, newspaper or magazine. It, obviously, helped the students made connection to the real world. Consequently, it increased their literacy competence and soft skill, that is the students are able to communicate their ideas, opinion to their friends. Finally, the students are able to finish their project well. Ravitz [13] says that authentic material will help the students see the point behind completing the work.

Furthermore, it was found that the role of the teacher shifts from the beginning to the end of the process of teaching learning English using Project based model. While the teacher introduced the concepts and background knowledge initially, the role of the teacher gradually diminished by the end of the project based on a gradual release of responsibility and allowing students voice and choice in the project (Larmer, 2014). This model allowed the students to learn the skills and knowledge when they needed to complete their task.

In short, to have literacy skills the teacher implemented PjBL since it provided opportunities for students to develop their confidence and independence so that their literacy skills could be improved. The students also had opportunity to show their project and perform their presentation about it. Here, they practiced to communicate their results.

\section{CONCLUSION AND SUGGESTION}

It can be concluded that teaching English using Project Based Learning model offers many benefits. It can motivate the students to learn something new. It can also allow students to critically think and develop a deeper understanding of the material because of the authenticity of the projects. Students are able to make real-world connections and the choice within the project allows them to have a sense of ownership of their work, which motivates them to produce higher quality projects. Moreover, the result of this research showed that many authentic materials and better facilities can support the improvement of students' literacy skill.

It is recommended that the teacher should implement many kinds of model in EFL teaching and facilitate the process of teaching learning to make the students active. The teacher should give more chance for them to express their arguments and experiences. It will automatically motivate the students to develop their skills.

\section{REFERENCES}

[1] S. L. Schneider and I. Kogan. The International Standard Classification of Education 1997: Challenges in the application to national data and the implementation in cross-national surveys. Int. Stand. Classif. Educ. (ISCED-97). An Eval. content criterion validity 15 Eur. Ctries., no. 2005, pp. 13-46.

[2] A. Mehtap Sagocak, E. Yilmaz, N. Karahan. Knowledge, Skills and Creativity in Vocational and Technical Education. Educational Research Association The International Journal of Educational Researchers, 4 (1) : pp. 13-21, 2013.

[3] Arik Susanti and A. Trisusana. EFL Materials Development Based on Project Based Learning for Vocational High School. Advances in Social 
Science, Education and Humanities Research (ASSEHR), volume 108. Atlantis Press, 2017.

[4] Arik Susanti. The Integration of Character Building and Soft Skill Education to Increase Profesional Human Resources in Vocational High Schools, Proceeding of ICVET. Universitas Negeri Yogyakarta, 2011.

[5] Hakan Turkmen. Creative Thinking Skills Analyzes of Vocational High School Students. Journal of Educational and Instructional Studies in the World. Volume: 5, pp. 74, 2015.

[6] Doppelt, Y. Implementation and assessment of project based learning in a flexible environment. International Journal of Technology and Design Education, 13, 255-272, 2003.

[7] Mandigo J, Francis N, Lodewyk K, Lopez R. Physical literacy for educators. Physic Health Education;75:27, 2009.

[8] C. L. Chiang and H. Lee. The Effect of Project-Based Learning on Learning Motivation and Problem-Solving Ability of Vocational High School Students. International Journal of Information and Education Technology, Vol. 6, No. 9, pp. 709, 2016.

[9] Duffy, T.M. \& Cunningham, D.J. Constructivism: Implications for the design and delivery of instruction. In D.H. 2007.

[10] M. C. English and A. Kitsantas. Supporting student self-regulated learning in problem and project-based learning. Interdisciplinary Journal of Problem-Based Learning, vol. 7, no. 2, pp. 128-150, 2013.
[11] Wurdinger, S., Haar, J., Hugg, R., \& Bezon, J. A qualitative study using project-based learning in a mainstream middle school. Improving Schools, 10(2), 150-161, 2007.

[12] Akinoglu, O. Assessment of the inquiry-based project application in science education upon Turkish science teachers' perspectives. Education. 129(2), 202-215, 2008.

[13] Ravitz, J. Project based learning as a catalyst in reforming high schools. Paper presented at Annual Meetings of the American Educational Research Association. New York, NY, 2008.

[14] Grant, M. M., \& Branch, R. M. Project-based learning in a middle school: Tracing abilities through the artifacts of learning. Journal of Research on Technology in Education, 38(1), 65-98, 2005.

[15] Neo, M., \& Neo, T.-K. Engaging students in multimedia-mediated constructivist learning - Students' perceptions. Educational Technology \& Society, 12 (2), $254-266,2009$.

[16] Gubacs, K. Project-based learning: A student-centered approach to integrating technology into physical education teacher education. Journal of Physical Education, Recreation and Dance, 75(7), 33-37, 2004.

[17] Hammond, T. "So what?" Students' articulation of civil themes in middle-school historical account projects. The Social Studies, 101, 5459, 2010. 